\title{
DEVELOPMENT OF RADIOCARBON DATING METHOD FOR DEGRADED BONE SAMPLES FROM KOREAN ARCHAEOLOGICAL SITES
}

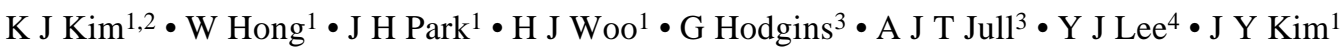 \\ ABSTRACT. The development of radiocarbon dating for degraded bone samples collected at Korean archaeological sites \\ has been successful through the characterization of raw bone $\mathrm{C} / \mathrm{N}$ ratios and application of an ultrafiltration method. It was \\ found that the $\mathrm{C} / \mathrm{N}$ ratios of raw bone samples are inversely proportional to the carbon content and residue amount after gela- \\ tinization. We have examined a few dozen Korean archaeological bone samples for this study. Well-preserved bone samples \\ are found to be physically dense. The range of $\mathrm{C} / \mathrm{N}$ ratios of Korean raw bone samples ranged from 3.4 to 74 . We found that \\ the $\mathrm{C} / \mathrm{N}$ ratios of degraded raw bone samples can be used to determine whether ${ }^{14} \mathrm{C}$ samples are acceptable for normal \\ pretreatment processing and eventual dating. The results of this study support that even if the $\mathrm{C} / \mathrm{N}$ ratio of a degraded raw \\ bone sample is 11, extraction of collagen for bone dating is feasible by a carefully designed ultrafiltration process. Our pre- \\ liminary ${ }^{14} \mathrm{C}$ dating results of a depth profile of Gunang-gul Cave, an archaeological site in Danyang, Korea, indicate that this \\ site has been either geologically or anthropologically disturbed in the past, with ${ }^{14} \mathrm{C}$ ages ranging from $28,910 \pm 200$ to \\ $48,090 \pm 1050 \mathrm{yr}$ BP. The C/N ratios of the collagen samples of Gunang-gul were determined to be 3.2-3.6. Our study \\ establishes a new guide for the pretreatment of degraded bone samples such as those collected in Korea for ${ }^{14} \mathrm{C}$ dating.
}

\section{INTRODUCTION}

Applications of radiocarbon bone dating have increased in both archaeological studies and forensic investigations. In Korea, archaeological bone materials are frequently excavated from numerous Paleolithic sites. The bones are often weathered and degraded due to the wet, hot Korean climate. In the case of a recently investigated archaeological cave site, Gunang-gul in Danyang, Korea, we found a soil profile that included bone materials in a matrix of paleosoil deposits and rock debris. ${ }^{14} \mathrm{C}$ dating of this site is important to understanding the Paleolithic culture of Korea. In order to obtain an accurate date of the weathered bone samples, we have developed a pretreatment procedure that optimizes the possibility of obtaining a reliable bone date.

One of the primary objectives of this research was to develop an effective pretreatment method for optimizing age determination of degraded bone samples. Understanding the characteristics of bone samples associated with high degradation is important for both archaeological and anthropological studies. It is true that many bone samples are difficult to date because the existing method is not designed for severely degraded bones. The most difficult environments for bone degradation are associated with caves and underground sites. Environmental factors that lead to the degradation of collagen ( $\mathrm{pH}$, hydrology of the matrix, oxygenation, temperature, and changes brought about by soil flora and fauna; Henderson 1987) are especially enhanced in underground environments such as caves. It is known that the protein component of bone undergoes relatively slow hydrolysis to peptides, which then break down into amino acids (Henderson 1987). In a burial environment, the spontaneous rearrangement of the inorganic crystalline matrix, which weakens the protein-mineral bond, leaves the bone susceptible to dissolution by the action of internal and external agents (Berna et al. 2003). Changes during diagenesis include random cross-linking, humification of parts of the molecule, attachment of exogenous humic materials, and hydrolysis with preferential loss of some amino acids (Hedges and van Klinken 1992).

\footnotetext{
${ }^{1}$ Korea Institute of Geoscience and Mineral Resources, 92 Gwahang-no, Yuseong-gu, Daejeon, 305-350, Korea.

${ }^{2}$ Corresponding author. Email: kjkim@kigam.re.kr.

${ }^{3}$ NSF Arizona AMS Laboratory, University of Arizona, 1118 E. Fourth St. Tucson, Arizona 85721, USA.

${ }^{4}$ Institute of Korean Prehistory, 890 Bongmyung-dong Heungduk-gu, Cheongju, Chungbuk, Korea.
} 
Collagen materials of well-preserved Paleolithic bones have $\mathrm{C} / \mathrm{N}$ ratios ranging between 3.1 and 3.4 (Jacobi et al. 2006). Other studies show the range of the collagen $\mathrm{C} / \mathrm{N}$ ratios for fossil bones as 3.1 to 11.1 for human and moa bones (Ajie et al. 1991), 3.1 to 8.3 for a dolphin bone and 3.0 to 3.5 for a molar fossil bone in Japan (Minami et al. 2004).

\section{EXPERIMENTAL}

We gathered about 40 old bones recognized to be various types of animal bones. Most of these samples were excavated bones from Paleolithic sites. The majority of these animal samples are deer bones and obtained from the Gunang-gul Cave site located in Danyang, Korea. We also included 3 well-preserved bone samples from the NSF Arizona AMS Laboratory. We cleaned these bone samples with pure water and ultrasonic cleaning steps. $\mathrm{C} / \mathrm{N}$ ratios of the untreated bone samples were determined using an elemental analyzer at KIGAM to determine the population trend of C/N ratios of Korean bone samples that we have received for ${ }^{14} \mathrm{C}$ dating.

The $\mathrm{C} / \mathrm{N}$ ratios of raw bone samples varied from 2.91 to 196 . We selected 8 representative bone samples with $\mathrm{C} / \mathrm{N}$ ratios of $3,5,8,11,34$, and 76 . These bone samples were then processed to obtain the ${ }^{14} \mathrm{C}$ age using the best characterized condition (i.e. $70{ }^{\circ} \mathrm{C}$ for $12 \mathrm{hr}$ ) of bone sample treatment determined Kim et al. (2010). We intended to determine the limit of the bone dating capabilities for Korean bone samples in order to determine the acceptable range of untreated bone $\mathrm{C} / \mathrm{N}$ ratios for commercial samples submitted to KIGAM. Figure 1 shows various raw bone samples and microscopic images for 2 fossilized bone samples of this study. Samples were also converted to collagen at $70{ }^{\circ} \mathrm{C}$ using the methods described in Kim et al. (2010). Collagen samples were also separated with 4 Centriprep ${ }^{\circledR}$ filters of different molecular sizes: 3, 10, 30, and $50 \mathrm{kD}$.

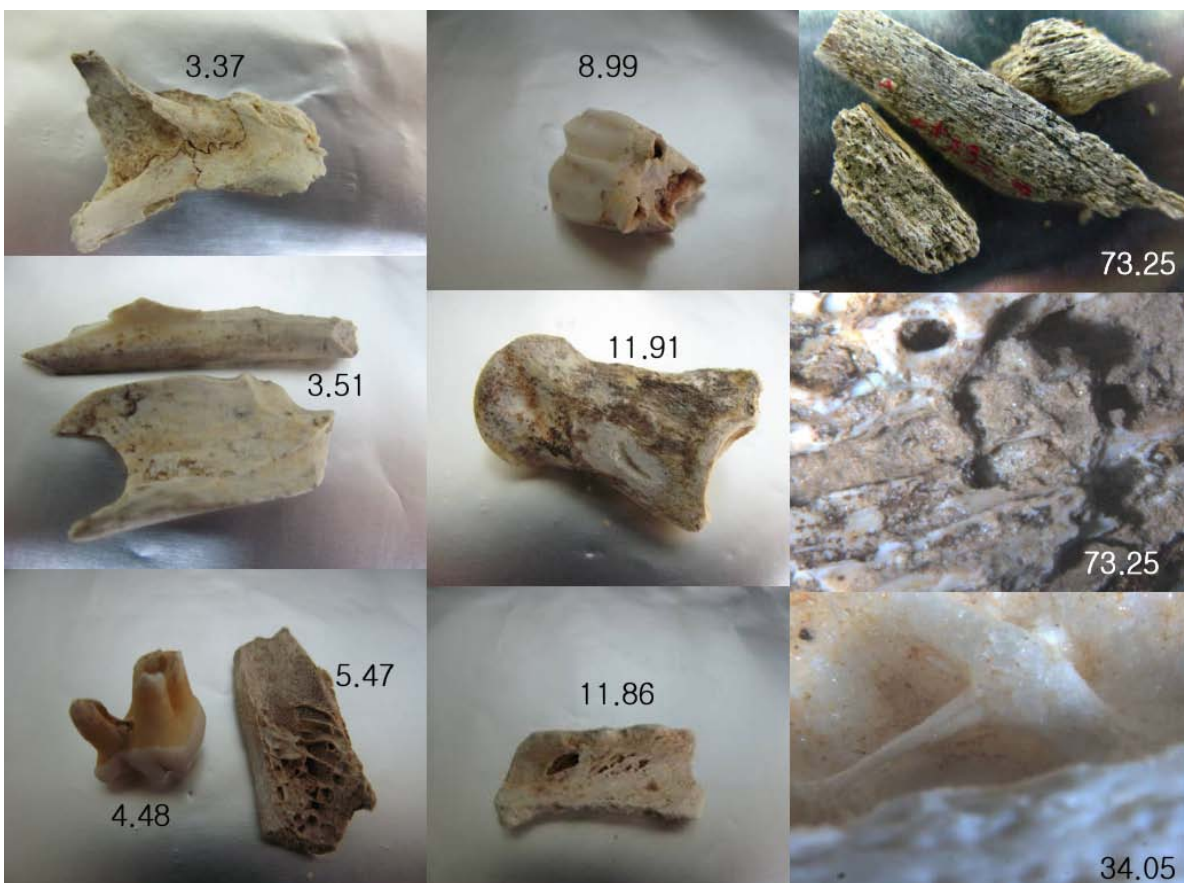

Figure 1 Various raw bone samples with corresponding $\mathrm{C} / \mathrm{N}$ ratios and microscopic images of 2 fossilized bone samples are shown. Untreated bone $\mathrm{C} / \mathrm{N}$ ratios obtained by an elemental analyzer are indicated. 


\section{RESULTS}

\section{C/N Ratios of Various Archaeological Bone Samples}

Figure 2 shows the relationship between bone $\mathrm{C} / \mathrm{N}$ ratios and carbon content of various raw bone samples collected in Korea, as well as 3 bone samples from the NSF Arizona AMS Laboratory. The point at the far-right side of the figure is associated with modern cow bone $(\mathrm{C} / \mathrm{N}=2.91 ; \mathrm{C} \%=$ 18.49) and well-preserved samples have lower $\mathrm{C} / \mathrm{N}$ ratios with higher carbon content. The well-preserved bone samples have raw bone $\mathrm{C} / \mathrm{N}$ ratios of $\sim 3$ and they are much denser than those associated with higher $\mathrm{C} / \mathrm{N}$ ratios. It is known that $\mathrm{C} / \mathrm{N}$ ratios represent the degree of the degradation of bone samples. Well-preserved Paleolithic bone samples have C/N ratios ranging from 3.1 to 3.4 (Jacobi et al. 2006). The raw $\mathrm{C} / \mathrm{N}$ ratios of the Korean archaeological bone samples ranged from 3 to 196 with nitrogen contents from $0.02 \%$ to $4.77 \%$. The nitrogen range compares well with the reference of nitrogen content (\%) of 5 classified whole bone materials in Stafford et al. (1988).

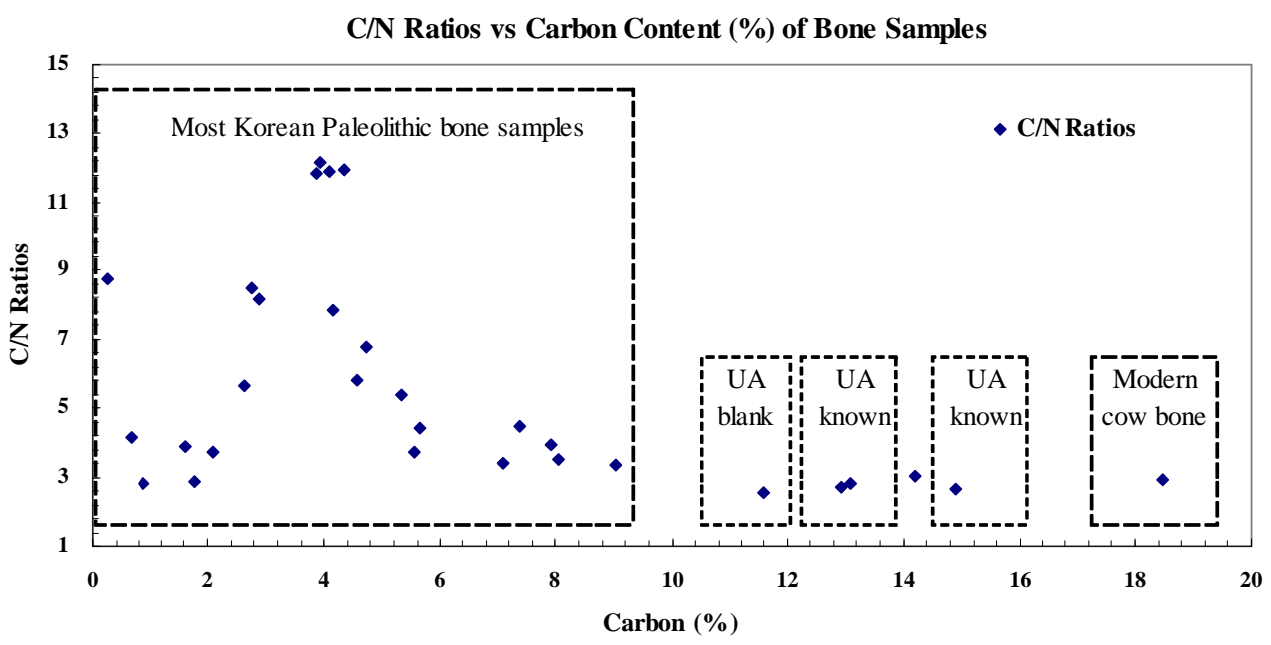

Figure 2 The relationship between $\mathrm{C} / \mathrm{N}$ ratios and carbon content of raw bone samples submitted for ${ }^{14} \mathrm{C}$ dating at KIGAM (UA = University of Arizona AMS lab).

\section{Collagenization of Degraded Bones}

Eleven bone samples associated with various $\mathrm{C} / \mathrm{N}$ ratios of raw bone materials from 3 to 73 were processed to extract collagen fractions. For the sample with a raw bone $\mathrm{C} / \mathrm{N}$ of 7.85 , its collagen fraction size was $<10 \mathrm{kD}$ but $>3 \mathrm{kD}$ (i.e. 10-kD molecular weight fraction cutoffs) (Figure 3). Also, there might be some collagen fraction smaller than $10 \mathrm{kD}$. However, a blank sample obtained from the NSF Arizona AMS laboratory with a $\mathrm{C} / \mathrm{N}$ ratio of 2.55 displayed a residual concentrated fraction using the $30-\mathrm{kD}$ filter. This implies that the Arizona blank sample is well preserved. The most abundant collagen is yielded using filters of 30 to $50 \mathrm{kD}$.

The $\mathrm{C} / \mathrm{N}$ ratios of all extracted collagen samples from the degraded bone samples acquired at Guang-gul Cave ranged from 3.23 and 3.56. This suggests that the collagen extraction methods for degraded bone samples established from this study are feasible for reliable bone dating applications. Figure 3 shows the normalized bone collagen amount per $1 \mathrm{~g}$ for various bone materials with respect to their bone $\mathrm{C} / \mathrm{N}$ ratios. The raw bone $\mathrm{C} / \mathrm{N}$ ratios are a good parameter for estimating collagen preservation and thus useful for ${ }^{14} \mathrm{C}$ dating. We take a raw bone $\mathrm{C} / \mathrm{N}$ ratio of 11 as indicative of a sample 


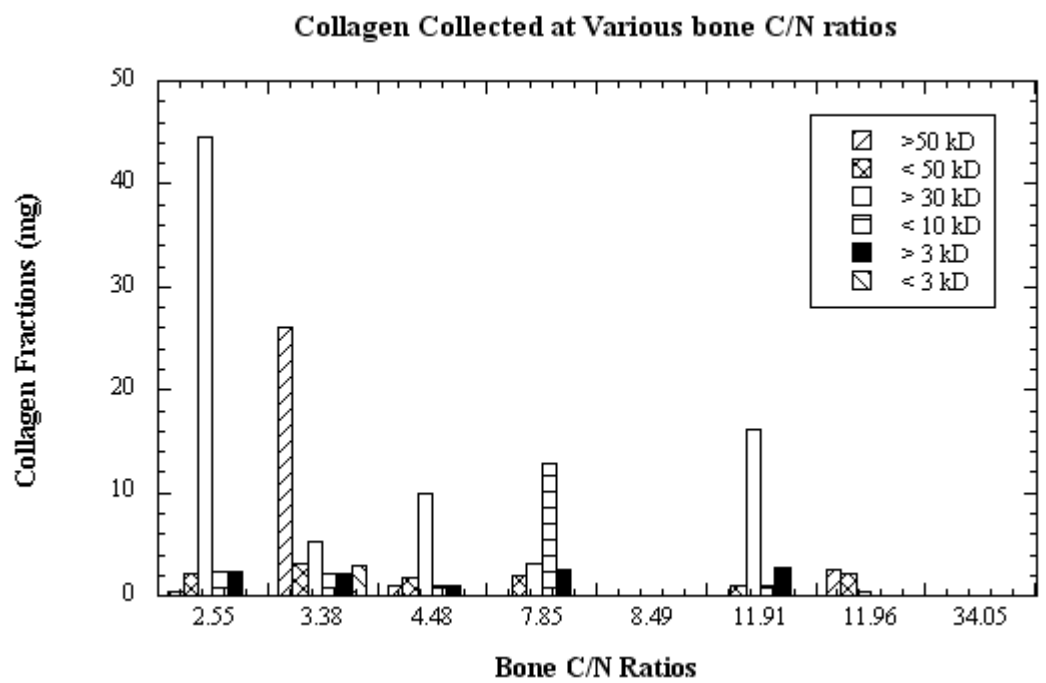

Figure 3 Normalized collagen amount per $1 \mathrm{~g}$ for various bone samples whose $\mathrm{C} / \mathrm{N}$ ratios range from 2.55 to 34.05 .

that can yield sufficient collagen for dating. Also apparent from Figure 3 is that the collagen molecular weight does not depend on the bone $\mathrm{C} / \mathrm{N}$ ratios. However, collecting all collagen fractions except the smallest fraction (i.e. $3 \mathrm{kD}$ ) will be helpful in increasing the datable collagen amount.

The age of the bone blank sample from the University of Arizona was determined to be 50,000 yr BP. Unlike the blank sample, all of the Korean samples were from more degraded conditions and associated high bone $\mathrm{C} / \mathrm{N}$ ratios. Figure 4 shows the raw bone $\mathrm{C} / \mathrm{N}$ ratios with respect to the residue on the glass filter. Samples with lower bone $\mathrm{C} / \mathrm{N}$ ratios tend to have higher residue on the filter. The relatively well-preserved bone samples of this study show residue amounts of $2-6 \%$ on the glass filter after collagenization.

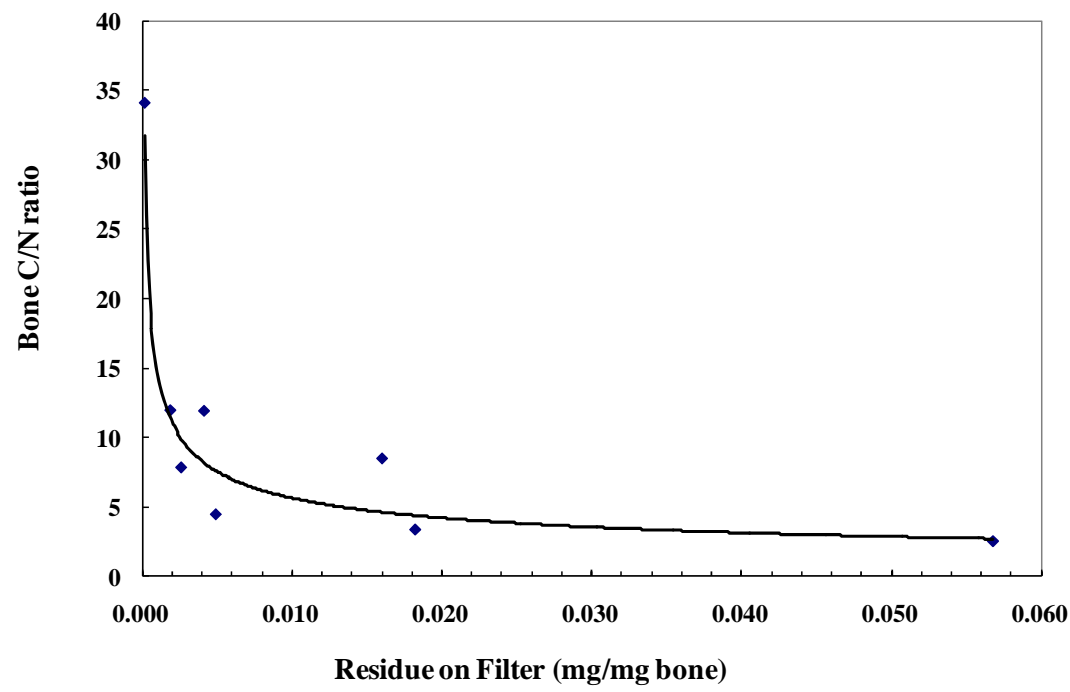

Figure 4 The bone $\mathrm{C} / \mathrm{N}$ ratio with respect to the residue on the glass filter. Lower bone $\mathrm{C} / \mathrm{N}$ ratios tend to have higher residue fractions. 


\section{Radiocarbon Ages of Gunang-gul Cave from a Paleolithic Site in Danyang, Korea}

As a final step of this study, we obtained ${ }^{14} \mathrm{C}$ ages for degraded bone samples collected at Gunanggul, a prehistoric cave site in Danyang, Korea. The bone samples of this cave site were identified to be mostly (95\%) deer bones. A few human bones were found, which were not available for dating. We processed deer bones and a deer tooth. Figure 5 shows the locations of sampling areas in the cave. The samples labeled TA and KA are located near the wall and central part of the cave, respectively. Samples labeled KATA were from the area straddling KA and TA. Table 1 shows the ${ }^{14} \mathrm{C}$ ages for Gunang-gul samples and the $\mathrm{C} / \mathrm{N}$ values for both bone and collagen materials. The ${ }^{14} \mathrm{C}$ ages range from 28,910 \pm 200 to $48,090 \pm 1050 \mathrm{yr} \mathrm{BP}$ (Figure 6). Some materials acquired at greater depths were younger than those samples collected at shallower depths, suggesting a disturbance at $160 \mathrm{~cm}$ depth either by geological process or anthropological activities. As shown in Figure 5, Gunang-gul Cave rock debris falls periodically from the ceiling of the cave and the ground surface of the cave is uneven. Gunang-gul has been partially excavated a few times since the first excavation in 1997. The bone materials of this study were collected from the cave in 2007, at which time there was evidence of a partial collapse observed within the cave.

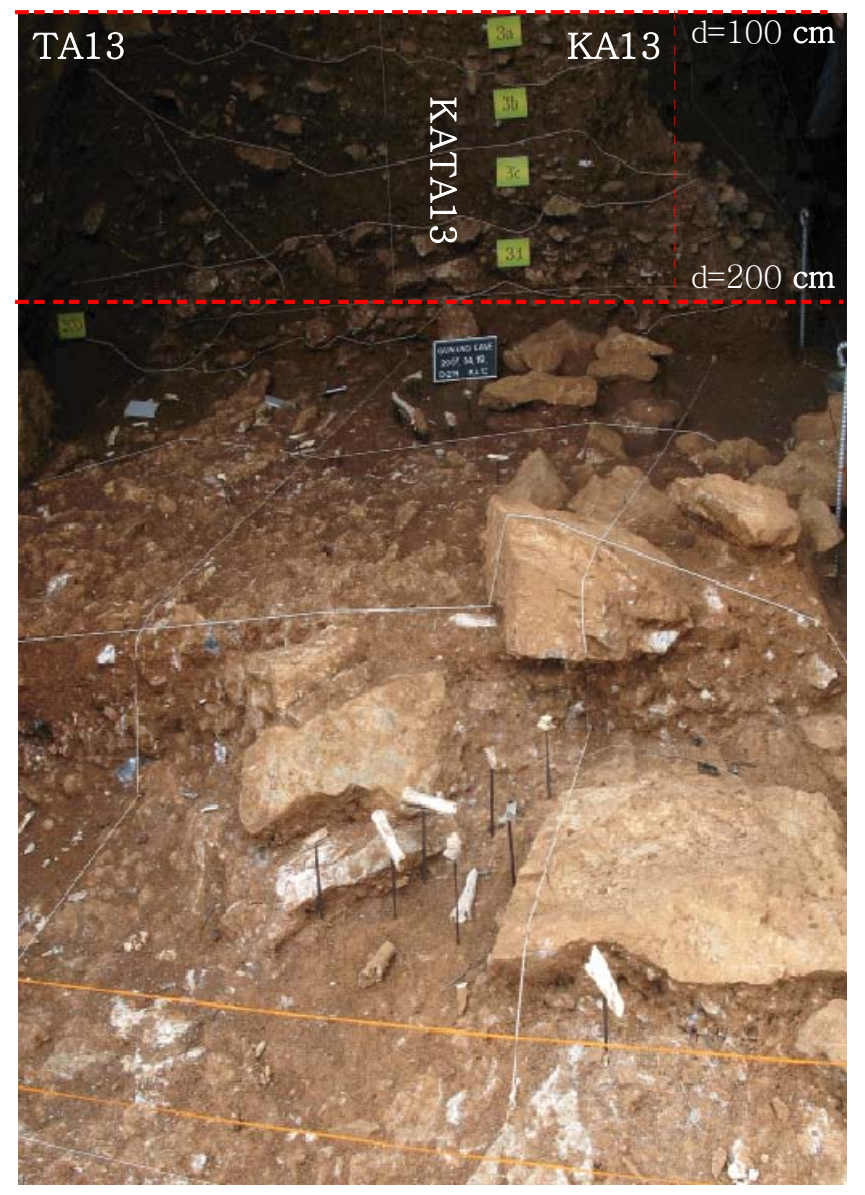

Figure 5 Photo of the bone sample collection site at Gunang-gul 
Table 1 Sample information and dating results. The bone and tooth samples are from Gunang-gul Cave; the tusk is a blank sample used at the NSF Arizona AMS lab.

\begin{tabular}{|c|c|c|c|c|c|c|c|c|}
\hline \multirow[b]{2}{*}{ Sample ID } & \multirow{2}{*}{$\begin{array}{l}\text { Depth } \\
\text { (cm) }\end{array}$} & \multirow[b]{2}{*}{ Material } & \multicolumn{2}{|c|}{$\mathrm{C} / \mathrm{N}$} & \multicolumn{2}{|c|}{${ }^{14} \mathrm{C}$ age (yr BP) } & \multicolumn{2}{|c|}{ Arizona } \\
\hline & & & Raw bone & Collagen & KIGAM & Arizona & Coll. \% & Carbon \% \\
\hline TBn080008 & 110 & Bone & 3.51 & 3.39 & $48,090 \pm 1050$ & - & - & - \\
\hline TBn080002 & 124 & Tooth & 4.48 & 3.23 & $34,310 \pm 450$ & - & - & - \\
\hline AA76269 & 127 & Bone & - & - & - & $>35,800$ & 3.8 & 31 \\
\hline AA76270 & 135 & Bone & - & - & - & $38,100 \pm 2800$ & 4.6 & 31.3 \\
\hline TBn080003 & 139 & Bone & 7.85 & 3.27 & $40,740 \pm 660$ & $>36,900$ & 3 & 28.4 \\
\hline AA76272 & 145 & Bone & - & - & - & $40,900 \pm 3900$ & $3.6^{\mathrm{a}}$ & 26.9 \\
\hline TBn080007 & 149 & Bone & 3.7 & 3.44 & $39,170 \pm 420$ & - & - & - \\
\hline TBn080004 & 156 & Bone & 11.91 & 3.43 & $46,210 \pm 1260$ & $>38,700$ & 5.5 & 32.8 \\
\hline TBn080001 & 169 & Bone & 3.38 & 3.28 & $35,900 \pm 420$ & $>32,800$ & $0.6^{\mathrm{a}}$ & 12 \\
\hline AA76275 & 180 & Bone & - & - & - & $>41,100$ & 2.6 & 24.3 \\
\hline TBn080006 & 199 & Bone & 11.86 & 3.56 & $28,910 \pm 200$ & - & - & - \\
\hline TBn080005 & 210 & Bone & 11.96 & 3.43 & $33,700 \pm 380$ & - & - & - \\
\hline TBn080009 & - & Blank, tusk & 2.55 & 3.09 & $52,390 \pm 1710$ & - & - & - \\
\hline TBn080006 & - & Blank, tusk & 2.55 & 3.16 & $49,660 \pm 1970$ & - & - & - \\
\hline
\end{tabular}

a"Poor collagen." Samples for the depths 139, 156, and $169 \mathrm{~cm}$ were chosen for the analytical comparison between the KIGAM and Arizona laboratories.

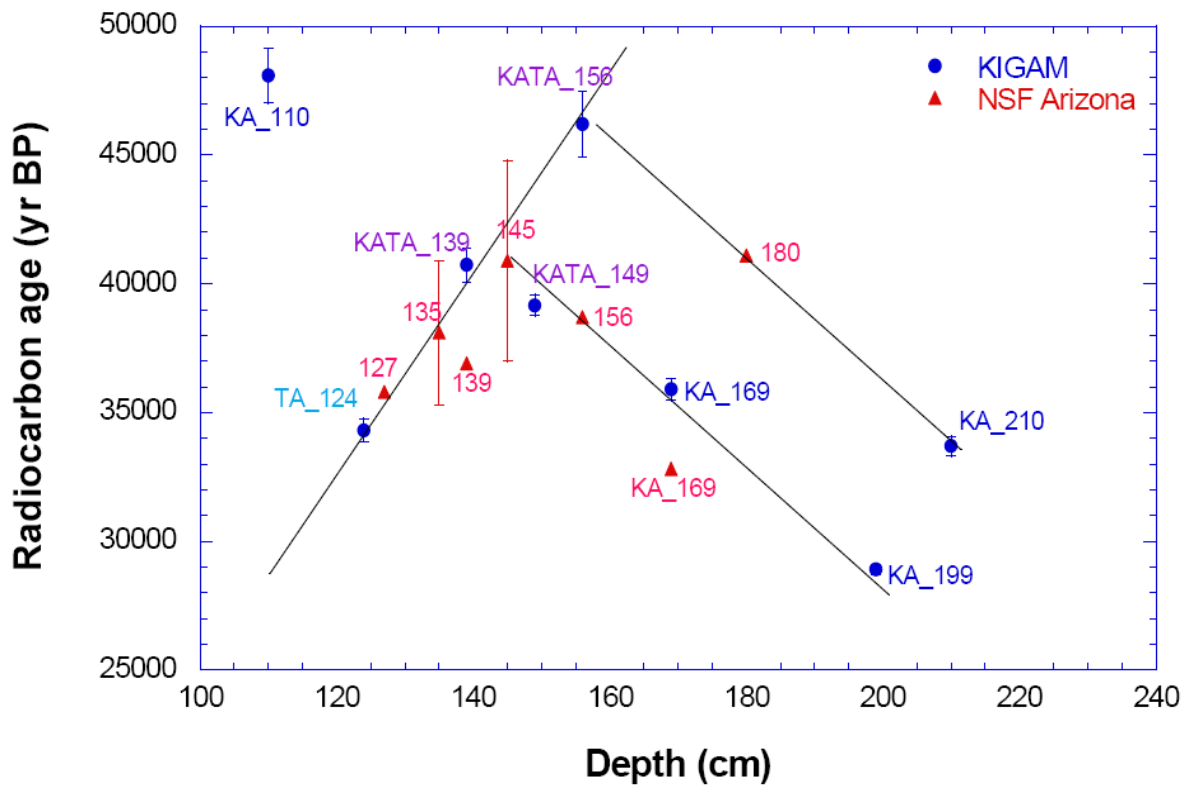

Figure $6{ }^{14} \mathrm{C}$ ages of bone materials acquired from the prehistoric Gunang-gul Cave, determined at the KIGAM and Arizona labs. The ${ }^{14} \mathrm{C}$ ages determined at Arizona are minimum ages and experimental errors are not provided. A possible scenario associated with either geological or anthropological event is described as the collapsed top layer at a certain time into a lower site of the cave.

\section{CONCLUSIONS}

Obtaining ${ }^{14} \mathrm{C}$ ages of degraded bone samples is a challenging task for Korean archaeological sampling. Due to the local climate, Paleolithic bone samples appear not to be as well preserved as samples from other parts of the world. Our goal has been to better understand the $\mathrm{C} / \mathrm{N}$ ratio of raw 
bone samples and how it relates to collagen quality, as well as maximizing the collection of all possible collagen fractions in order to optimize the datable collagen materials for ${ }^{14} \mathrm{C}$ dating. Since the determination of datable bone samples for ${ }^{14} \mathrm{C}$ dating cannot be solely based on the physical appearance, an initial investigation of the bone $\mathrm{C} / \mathrm{N}$ ratio is found to be effective up to a value of 11 . We note the collagen molecular size for degraded bone samples appears not to be related simply to the bone $\mathrm{C} / \mathrm{N}$ ratio. Our ${ }^{14} \mathrm{C}$ dating results of the Paleolithic Gunang-gul Cave site in Danyang, Korea, ranged from 28,910 \pm 200 and 48,090 $\pm 1050 \mathrm{yr} \mathrm{BP}$. Due to the large range, this site is thought to be disturbed by either geological or anthropological activities in the past. Further investigation with more sample analyses of this site is required to unravel the archaeological history of the Gunang-gul site, as well as possible modification of the site either by geological or man-made processes.

\section{ACKNOWLEDGMENTS}

We thank Dr John Southon of the AMS Laboratory at the University of California, Irvine, for the scientific advice for bone dating techniques. We also thank the staff at the KIGAM and Arizona AMS laboratories for their assistance. This work has been partially supported by the research projects 08-530270 and 10-3611 of the Korea Institute of Geoscience and Mineral Resources. The work at Arizona was supported in part by NSF grant EAR06-22305.

\section{REFERENCES}

Ajie HO, Hauschka PV, Kaplan IR, Sobel H. 1991. Comparison of bone collagen and osteocalcin for determination of radiocarbon ages and paleodietary reconstruction. Earth and Planetary Science Letters 107(2): 380-8.

Berna F, Matthews A, Weiner S. 2003. Solubilities of bone mineral from archaeological sites: the recrystallization window. Journal of Archaeological Science 31(7):867-82.

Hedges REM, van Klinken GJ. 1992. A review of current approaches in the pretreatment of bone for radiocarbon dating by AMS. Radiocarbon 34(2):279-91.

Henderson J. 1987. Factors determining the state of preservation of human remains. In: Boddington A, Garland AN, Janaway RC, editors. Death, Decay, and Reconstruction. Manchester: Manchester University Press. p 43-54.
Jacobi RM, Higham TFG, Bronk Ramsey C. 2006. AMS radiocarbon dating of Middle and Upper Palaeolithic bone in the British Isles: improved reliability using ultrafiltration. Journal of Quaternary Science 21(5): 557-73.

Kim KJ, Hong W, Park JH, Woo HJ, Hodgins G, Jull AJT. 2010. Development of radiocarbon dating methods for modern bone collagenization. Radiocarbon 52(4): 1657-9.

Minami M, Muto H, Nakamura T. 2004. Chemical techniques to extract organic fractions from fossil bones for accurate ${ }^{14} \mathrm{C}$ dating. Nuclear Instruments and Methods in Physics Research B 223-224:302-7.

Stafford Jr TW, Brendel K, Duhamel RC. 1988. Radiocarbon, ${ }^{13} \mathrm{C},{ }^{15} \mathrm{~N}$ analysis of fossil bone: removal of humates with XAD-2 resin. Geochimica et Cosmochimica Acta 52(9):2257-67. 